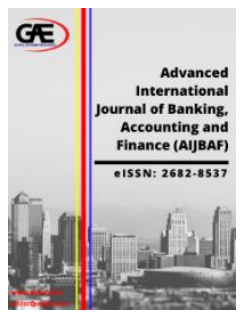

\author{
ADVANCED INTERNATIONAL JOURNAL OF \\ BANKING, ACCOUNTING AND FINANCE \\ (AIJBAF) \\ WWW.aijbaf.com
}

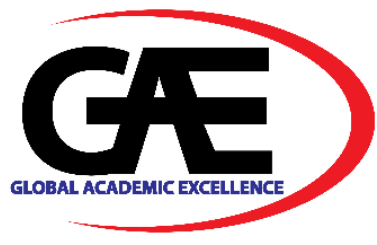

\title{
TRADE OPENNESS AND ECONOMIC GROWTH IN MALAYSIA FROM 1980-2018
}

\author{
Khairunisah Kamsin ${ }^{1}$, James Alin ${ }^{2}$, Mori Kogid ${ }^{3}$ \\ 1 Faculty of Business, Economics and Accountancy, Universiti Malaysia Sabah, Kota Kinabalu, Malaysia. \\ Email: khairunisah1703@gmail.com \\ 2 Faculty of Business, Economics and Accountancy, Universiti Malaysia Sabah, Kota Kinabalu, Malaysia. \\ Email:maejames@ums.edu.my \\ 3 Faculty of Business, Economics and Accountancy, Universiti Malaysia Sabah, Kota Kinabalu, Malaysia. \\ Email: edy@ums.edu.my \\ * Corresponding Author
}

\section{Article Info:}

Article history:

Received date: 20.10 .2020

Revised date: 09.11.2020

Accepted date: 23.11.2020

Published date: 01.12.2020

\section{To cite this document:}

Kamsin, K., Alin, J., \& Kogid, M. (2020). Trade Opennes and Economic Growth in Malaysia from 1980-2018. Advanced International Journal of Banking, Accounting, and Finance, 2 (5), 55-63.

DOI: $10.35631 /$ AIJBAF.25005.

This work is licensed under $\underline{\text { CC BY } 4.0}$

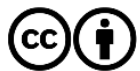

\begin{abstract}
:
This study analyses the impact of trade openness on economic growth, between 1980-2018. This study using the unit root test (ADF) and the Philip and Perron (PP) test to examine the stationary of the time series data, the ARDL test to show the cointegration and long run relationship between variables, and the Wald test to show the short-term effect of the variables. The finding shows that all variables have a long-run relationship with economic growth and the bound test shows that foreign direct investment (FDI) and the Real Effective Exchange Rate (REER) have a positive and significant relationship with economic growth. The study also found that openness is correlated with economic growth in Malaysia.
\end{abstract}

Keywords:

Trade Openness, Economic Growth, FDI, Capital Formation, Real Effective Exchange Rate

\section{Introduction}

It has long been recognised that trade openness has an important role in a country's economic growth. Due to this importance, trade openness has attracted much research until now. Trade as a development path which will lead to increased economic growth in most developing countries (Merale et al. 2015). At the beginning of the twentieth century, many developing Copyright (C) GLOBAL ACADEMIC EXCELLENCE (M) SDN BHD - All rights reserved 
Volume 2 Issue 5 (December 2020) PP. 55-63

DOI 10.35631/AIJBAF.25005

countries such as Malaysia has been regulated and improve their economic by doing new economic regulation and highly regulated import. The regulation was made to protect the economy globally. However, when the economic policies changed in 1980, the barrier for Malaysia to trade and investment decreased due to the shift from import to export promotion strategies. This policy has helped Malaysia to increase worldwide trade and investment and boost its economic growth. Other than that, Malaysia has become one of the top 30 countries in the global export and import activities. Since international trade is parallel with the economic growth expending trade, especially in the export and import sector. Consequently, this has led to the establishment of large-scale industry.

Thus, trade openness plays the main role as an engine to generate more benefit to the country. This paper will provide a detailed discussion about the role of trade openness, export and import to a country's economic growth by focusing on the slow growth theory and endogenous theory to make this discussion more relevant with the result. Other than that, this study also including foreign direct investment, capital formation, and real effective exchange rate to provide accurate results since this variable has been pointed out in the theories.

\section{Literature review}

The relationship between trade openness and economic growth has been widely debated and has become one of the most widely researched areas in economics. Based on the Grossman and Helpman (1991) trade openness found having a positive impact on economic growth by promoting the technology that will lead the productivity, export revenues and international trade. At present, the research on this topic is still appealing since there is a lack of clear definition of trade openness. Various countries have opened their economy to boost their economic growth and development. Trade openness is an indicator of economic growth to achieve a country's economic goal. Jamilah et al. (2016) found that increased trade openness will lead to positive economic growth in OECD countries.

Keho (2017) examined the impact of trade openness on economic growth. The case in Cote d Ivoire reflects the role of capital formation as an engine to accelerate economic growth in this country. The result shows that this variable has a strong and positive relationship in the short and long run. This can be concluded that increasing capital to add investment could bring more benefits to their home country. This argument was supported by Adhikary(2011), who indicated that foreign direct investment and level of capital formation has a significant and positive relationship to economic growth. Meanwhile, Husein and Saidin (2012) also found that foreign direct investment, trade openness and fixed capital formation could generate economic growth in ASEAN-4 countries. Therefore, trade openness plays a major role in the economic growth of developing countries.

There are several dimensions of trade openness which have been discussed in the previous literature such as trade index but in this study only focus to the term of trade openness, which refers to the sum of import and export as a percentage of gross domestic product (GDP). Based on the previous literature, trade openness has a positive impact on economic growth by increasing trade expansion and increase the externalities in the non-export sector (Edwards 1993). The relationship between foreign direct investment, import and export have been shown to give the benefit to the economic performance in the country. 
Volume 2 Issue 5 (December 2020) PP. 55-63

DOI 10.35631/AIJBAF.25005

This result was found from the previous literature who examine the relationship of both variables which is exchange rate and economic growth by Malcolm and Tzvetana (1998) show that they were no significant relationship between exchange rate and economic growth in Kenya. Opposite form this finding the study by David and Guillermo (2005) found that, the real exchange rate has a relationship with gross domestic product (GDP) when they are doing the analysis of currency crisis on economic growth for 28 countries. they also found that while the currency crisis the exchange rate leads the intensity of dropping economic growth at that time.

Vogiatzoglou and Nguyen (2016) suggest that foreign direct investment will lead to the transformation of technology, economical and at the same time, technological progress. Since it is one of the engines to generate the economic growth, it is found significant to economic growth. Besides that, economic theory suggests that medium-term and long-term growth in one country is led by investment and gross fixed capital formation. besides that, Makun(2017) examine the effect of trade openness on economic growth in Malaysia found that, trade openness has a positive relation with the output growth in this county. This can be found when human capital has a main role to generate more output growth which give a positive impact of trade openness. In contrast, the study of trade openness and economic growth: panel evidence by review (2015) indicate that trade openness does not lead economic growth since this study found that lower trade barriers will not affect or influence increasing or decreasing economic growth.

The involvement in the international trade will benefit the exchange rate performance due to the effect of exchange rate volatility from the international trade and investment AbuDalu A, et al. (2014). Trade openness has been found to have a positive relationship with economic performance in the long run because of the level of investment that will influence the effect on economic growth (Musila and Yiheyis, 2015). Thus, empirical studies on trade openness impact to economic growth still inconclusive because of the mixed finding of previous studies. This result was supported by Jawaid (2014) which indicate that trade openness has a positive relationship among export and economic growth where this study found that using capital goods will increase production in Pakistan.

\section{Methodology}

This study focuses on the short-term and long-term relationship between trade openness and economic growth. This study using sum of export and import as a percentage of gross domestic product as a proxy of trade openness meanwhile gross product as a proxy of economic growth. To show the relationship between this variables this study also including other important variables such as real effective exchange rate (LEER), Foreign direct investment (LFDI), gross capital formation (LCF), export (LX) and also import (LM) to avoid The relationship was estimated by using the proposed ARDL bound test introduced by Pesaran et al. (2001). This study used 38 samples of time series data from 1980-2018. This study assumes that Cobb Douglas production function is given below:

$$
y_{t}=a_{t} k_{t} \text {. }
$$

where $\mathrm{Y}$ is the gross output produced by the economy, and $\mathrm{K}$ and $\mathrm{L}$ are capital and labour as a factor of production in the given period, t. Based on the model, the capital is assuming 
production function not following diminishing returns. Besides, the endogenous growth capital creates policies which maintain openness, competition, and innovation which promotes economic growth. Therefore, equation (2) is augmented as:

$$
\begin{aligned}
& \Delta(L G D P)_{i t}=\beta_{0}+\beta_{1} \Delta \text { trade openness }(L T O)_{i t}+ \\
& \quad \beta_{2} \text { real effective exchange rate }(L R E E R)_{i(t-1)}+
\end{aligned}
$$

$$
\beta_{3} \text { foreign direct investment }(L F D I)_{i(t-1)}+\beta_{4} \text { capital formation }(L C F)_{i(t-1)}+\varepsilon_{i t}
$$

From this equation, $\mathrm{YGDP}_{\mathrm{t}}$ explains the independent variable, specifically the gross domestic product (GDP) Per Capita, and trade openness as a sum of export and import as a percentage of GDP $\left(\mathrm{TO}_{\mathrm{t}}\right), \varepsilon_{\mathrm{t}}$ denotes the error term.

$\Delta(L G D P)_{i t}=\beta_{0}+\beta_{1} \Delta \operatorname{export}(L X)_{i t}+\beta_{2}$ real effective exchange rate $(L R E E R)_{i(t-1)}+$ $\beta_{3}$ foreign direct investment $(L F D I)_{i(t-1)}+\beta_{4}$ gross capital formation $(L C F)_{i(t-1)}+\varepsilon_{i t}$

Previous studies show that many variables influence economic growth. Thus, these variables should be included in GDP variables to avoid bias in regressions and to examine the relationship between trade openness and economic growth. The explanatory variables which will be included in this study is the effective exchange rate $\left(\operatorname{REER}_{t}\right)$, gross capital formation $\left(\mathrm{CF}_{\mathrm{t}}\right)$, foreign direct investment $\left(\mathrm{FDI}_{\mathrm{t}}\right)$ and export $\left(\mathrm{E}_{\mathrm{t}}\right)$. And to explain the benefits of trade openness to economic growth, the variables included in the equation (2) were modified as shown in equation (3).

$\Delta(L G D P)_{i t}=\beta_{0}+\beta_{1} \Delta$ import $(L M)_{i t}+\beta_{2}$ real effective exchange rate $(L R E E R)_{i(t-1)}+$ $\beta_{3}$ foreign direct investment $(L F D I)_{i(t-1)}+\beta_{4}$ gross capital formation $(L C F)_{i(t-1)}+\varepsilon_{i t}$

where $\mathrm{M}$ is the import in given period t REER refer to real effective exchange rate, $\mathrm{CF}$ denotes to capital formation, FDI refers to foreign direct investment and $\varepsilon_{t}$ denotes the error term.

\section{Result and Analysis}

The procedure involves testing for the unit root test for each variable, which can be seen in Table 1. Two-unit root tests were performed in this study, specifically the Augmented Dickey Fuller (ADF) and Phillip and Perron (PP) test. The test was used to determine the order of integration of each variable. Based on the result of unit root test, it was found that gross domestic product(LGDP), trade openness (LTO), capital formation(LCF), real effective exchange rate (LREER), export (LX), import (LM) not stationary at the level, but stationary at the first difference for both ADF and PP test. Meanwhile, foreign direct investment (LFDI) was found to be significant at the $1 \%$ significant level. Based on this result, it can be concluded that the data used in this study fulfil the requirement to perform the ARDL test. 
Table 1: Unit Root Test

\begin{tabular}{|c|c|c|c|c|c|}
\hline \multirow[t]{2}{*}{ VARIABLES } & \multirow{2}{*}{$\begin{array}{l}\text { MODEL } \\
\text { SPESIFICATION }\end{array}$} & \multicolumn{2}{|c|}{ ADF TEST } & \multicolumn{2}{|l|}{ PP TEST } \\
\hline & & LEVEL & $\begin{array}{l}1^{\mathrm{ST}} \\
\text { DIFF }\end{array}$ & LEVEL & $1^{\text {ST }}$ DIFF \\
\hline \multirow[t]{2}{*}{ LGDP } & Intercept & -0.398 & $-5.228^{*}$ & -0.411 & $-5.179 *$ \\
\hline & Intercept and Trend & -2.388 & $-5.153^{*}$ & -2.573 & $-5.098 *$ \\
\hline \multirow[t]{2}{*}{ LTO } & Intercept & -1.517 & $-3.771^{*}$ & -1.328 & $-3.766 *$ \\
\hline & Intercept and trend & -0.183 & $-4.287 *$ & -0.183 & $-4.114^{*}$ \\
\hline \multirow[t]{2}{*}{ LFDI } & Intercept & $-5.222 *$ & $-6.903^{*}$ & $-5.222 *$ & $-26.157 *$ \\
\hline & Intercept and Trend & $-5.257 *$ & $-6.803^{*}$ & $-5.260 *$ & $-25.539 *$ \\
\hline \multirow[t]{2}{*}{$\mathbf{L C F}$} & Intercept & -1.772 & $-5.443^{*}$ & -1.903 & $-5.439 *$ \\
\hline & Intercept and Trend & -2.138 & $-5.363^{*}$ & -2.371 & $-5.359 *$ \\
\hline \multirow[t]{2}{*}{ LREER } & Intercept & -1.184 & $-4.596^{*}$ & -1.164 & $-4.449 *$ \\
\hline & Intercept and Trend & -1.763 & $-4.557 *$ & -2.053 & $-4.777 *$ \\
\hline \multirow[t]{2}{*}{$\mathbf{L X}$} & Intercept & -1.887 & $-4.030 *$ & -1.309 & $-4.019 *$ \\
\hline & Intercept and Trend & -0.067 & $-4.819^{*}$ & -0.260 & $-5.286^{*}$ \\
\hline \multirow[t]{2}{*}{$\mathbf{L M}$} & Intercept & -1.255 & $-4.302 *$ & -1.418 & $-4.302 *$ \\
\hline & Intercept and Trend & -0.698 & $-4.470 *$ & -0.858 & $-4.484 *$ \\
\hline
\end{tabular}

Notes: The ADF and PP test includes the intercept and trend when testing for unit root test. The mark $*, * *$ and $* * *$ indicate that the coefficients are significant at the $10 \%, 5 \%$ and $1 \%$ level of significance, respectively.

\section{Detecting Long Run Relationship}

In order to proceed with the ARDL test, the result must be tested for long term relationship between the series of the variables. Since this study used three equations, which are E1,E2, and E3, by using max lag 4 and the critical value obtained suggested by Narayan(2004) for a small sample size between 30-80.In this light, if the F statistic is below the bound test value , the hypothesis cannot be rejected. Meanwhile, if the F statistic upper bounds test value, the hypothesis will be rejected. In case of this study, the number of $F$ statistic for all equation upper than the bound test, which is cointegration with each other and there is a long-term relationship between the variables. For E1, the best model followed for the SC is $(3,0,1,0,4)$ which revealed that the null hypothesis on no cointegration is $(8.93>5.532)$. This is followed by E2, using the best model of SC $(3,0,1,4,4)$. The result of F value is 10.395 , which more than the upper bound critical value which is 5.455. Thus, the null hypothesis for no cointegration was rejected at the $1 \%$ significant level. For the last equation $\mathrm{E} 3$, the result of null hypothesis for no cointegration is $(6.94>5.532)$ by using best model of SC, which is $(4,2,4,2,3)$. This result confirms that, the null hypothesis was rejected at the $1 \%$ significant level since $\mathrm{F}$ value is more than the upper bound critical value which stated in Table 2.0. 
Volume 2 Issue 5 (December 2020) PP. 55-63 DOI 10.35631/AIJBAF.25005

Table 2.0: Long Run Relationship

\begin{tabular}{|c|c|c|c|c|c|}
\hline Equation & Critical & Lower & Upper I (1) & F Value & RESULT \\
\hline $\begin{array}{l}\text { E } 1 \\
(3,0,1,0,4)\end{array}$ & $\begin{array}{l}\text { value for } F \\
\text { statistics } \\
1 \% \\
5 \% \\
10 \%\end{array}$ & $\begin{array}{l}1(0) \\
4.093 \\
2.947 \\
2.46\end{array}$ & $\begin{array}{l}5.532 \\
4.088 \\
3.46\end{array}$ & 8.933 & COINTEGRATION \\
\hline $\begin{array}{l}\text { E } 2 \\
(3,0,1,4,4)\end{array}$ & $\begin{array}{l}\begin{array}{l}\text { Critical } \\
\text { value for } F \\
\text { statistics }\end{array} \\
1 \% \\
5 \% \\
10 \%\end{array}$ & $\begin{array}{l}\text { Lower } \\
\text { I (0) } \\
3.967 \\
2.893 \\
2.427\end{array}$ & $\begin{array}{l}\text { Upper I (1) } \\
5.455 \\
4 \\
3.395\end{array}$ & 10.395 & COINTEGRATION \\
\hline $\begin{array}{l}\text { E } 3 \\
(4,2,4,2,3)\end{array}$ & $\begin{array}{l}\begin{array}{l}\text { Critical } \\
\text { value for } \boldsymbol{F} \\
\text { statistics }\end{array} \\
1 \% \\
5 \% \\
10 \%\end{array}$ & 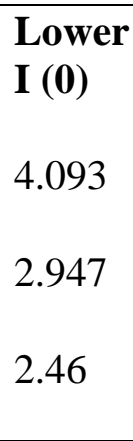 & $\begin{array}{l}\text { Upper I (1) } \\
4.093 \\
2.947 \\
2.46\end{array}$ & 6.937 & COINTEGRATION \\
\hline
\end{tabular}

Table 2.1: Bound Test

\begin{tabular}{|c|c|c|c|c|}
\hline Equation & Regressor & $\begin{array}{l}\text { SC } \\
\text { Lag }\end{array}$ & Coefficient & T Statistic \\
\hline \multirow{4}{*}{$\begin{array}{l}\text { E } 1 \\
(3,0,1,0,4)\end{array}$} & LFDI & 4 & $0.348 * *$ & 1.958 \\
\hline & LCF & 4 & -0.705 & -1.155 \\
\hline & LTO & 4 & -0.600 & -1.160 \\
\hline & LREER & 4 & $-2.621 *$ & -3.713 \\
\hline Equation & Regressor & $\begin{array}{l}\text { SC } \\
\text { Lag }\end{array}$ & Coefficient & T Statistic \\
\hline \multirow{4}{*}{$\begin{array}{l}\text { E } 2 \\
(\mathbf{1 , 0 , 1 , 1 , 1 )}\end{array}$} & LFDI & 3 & 1.825 & 0.492 \\
\hline & $\mathrm{LCF}$ & 3 & -9.524 & -0.476 \\
\hline & LREER & 3 & -1.192 & -0.188 \\
\hline & LX & 3 & 2.398 & 0.318 \\
\hline
\end{tabular}




\begin{tabular}{|lllll|} 
Equation & Regressor & SC & Coefficient & DOI 10.35631/AIJBAF.25005 \\
E 3 & Lag & & T Statistic \\
\multirow{2}{*}{$\mathbf{4 , 2 , 4 , 2 , 3 )}$} & LFDI & 4 & $0.516^{* *}$ & 2.339 \\
\cline { 2 - 5 } & LCF & 4 & 0.377 & 0.584 \\
\cline { 2 - 5 } & LREER & 4 & $-1.871 * * *$ & -2.015 \\
\cline { 2 - 3 } & LM & 4 & -0.252 & -0.323 \\
\hline
\end{tabular}

Notes: the bound test using Schwarz Criterion (SC) when testing the cointegration between variables and the mark $*, * *$ and $* * *$ indicate that the coefficients are significant at the $1 \%$, $5 \%$ and $10 \%$ level of significance, respectively.

\section{The Short-Term Analysis}

The result of Wald test explains the short-term relationship analysis as illustrated in the table below shows that for Malaysia, models E1 LFDI, LCF and LREER demonstrate a causal relationship with LGDP at the $1 \%$ significant level. Meanwhile, in the case of trade openness there is no causal relationship with LGDP since the Wald test statistics result is not significant. In the case of model E2 LFDI, LREER and LX are significant at the 1\% and 5\% significant level. By using this model, only LCF has no causal relationship with LGDP. For model E3, the result from the Wald test statistics show that all variables significant, reflecting LFDI, LCF, LREER and LM have a causal relationship with LGDP.

Table 3: Estimation of Short Run Restricted Error Correction Model (ECM) For Malaysia

Dependent Variable: GDP

\begin{tabular}{|c|c|c|c|c|}
\hline EQUATION & $\begin{array}{l}\text { NULL } \\
\text { HYPOTHESIS }\end{array}$ & $\begin{array}{l}\text { WALD TEST } \\
\text { STATISTIC }\end{array}$ & RESULT & $\begin{array}{l}\text { DIRECTION OF } \\
\text { CAUSALITY }\end{array}$ \\
\hline \multirow[t]{4}{*}{ E1 } & $\begin{array}{l}\text { LFDI does not } \\
\text { cause LGDP }\end{array}$ & $10.116^{*}$ & reject & $\begin{array}{l}\text { LFDI has a causal } \\
\text { relationship with LGDP }\end{array}$ \\
\hline & $\begin{array}{l}\text { LCF does not } \\
\text { cause LGDP }\end{array}$ & $5.904 *$ & reject & $\begin{array}{l}\text { LCF has a causal } \\
\text { relationship with LGDP }\end{array}$ \\
\hline & $\begin{array}{l}\text { LREER does } \\
\text { not cause } \\
\text { LGDP }\end{array}$ & $46.090^{*}$ & reject & $\begin{array}{l}\text { LREER has a causal } \\
\text { relationship with LGDP }\end{array}$ \\
\hline & $\begin{array}{l}\text { LTO does not } \\
\text { cause LGDP }\end{array}$ & 0.809 & $\begin{array}{ll}\text { Do } & \text { not } \\
\text { reject } & \end{array}$ & $\begin{array}{l}\text { LTO has no relationship } \\
\text { with LGDP }\end{array}$ \\
\hline \multirow[t]{4}{*}{ E2 } & $\begin{array}{l}\text { LFDI does not } \\
\text { cause LGDP }\end{array}$ & $4.227 * *$ & Reject & $\begin{array}{l}\text { LFDI has a causal } \\
\text { relationship with LGDP }\end{array}$ \\
\hline & $\begin{array}{l}\text { LCF does not } \\
\text { cause LGDP }\end{array}$ & 2.519 & $\begin{array}{ll}\text { Do } & \text { not } \\
\text { reject }\end{array}$ & $\begin{array}{l}\text { LCF has no causal } \\
\text { relationship with LGDP }\end{array}$ \\
\hline & $\begin{array}{lr}\text { LREER } & \text { does } \\
\text { not } & \text { cause } \\
\text { LGDP } & \end{array}$ & $38.401^{*}$ & Reject & $\begin{array}{l}\text { LREER has a causal } \\
\text { relationship with LGDP }\end{array}$ \\
\hline & $\begin{array}{l}\text { LX does not } \\
\text { cause LGDP }\end{array}$ & $7.074 *$ & Reject & $\begin{array}{l}\text { Lx has a causal } \\
\text { relationship with LGDP }\end{array}$ \\
\hline
\end{tabular}


Volume 2 Issue 5 (December 2020) PP. 55-63

DOI 10.35631/AIJBAF.25005

\begin{tabular}{|c|c|c|c|c|}
\hline \multirow[t]{4}{*}{ E3 } & $\begin{array}{l}\text { LFDI does not } \\
\text { cause LGDP }\end{array}$ & $14.878 *$ & Reject & $\begin{array}{l}\text { LFDI has a causal } \\
\text { relationship with LGDP }\end{array}$ \\
\hline & $\begin{array}{l}\text { LCF does not } \\
\text { cause LGDP }\end{array}$ & $15.330 *$ & Reject & $\begin{array}{l}\text { LCF has a causal } \\
\text { relationship with LGDP }\end{array}$ \\
\hline & $\begin{array}{ll}\text { LREER } & \text { does } \\
\text { not } & \text { cause } \\
\text { LGDP } & \end{array}$ & $37.899 *$ & Reject & $\begin{array}{l}\text { LREER has a causal } \\
\text { relationship with LGDP }\end{array}$ \\
\hline & $\begin{array}{l}\text { LM does not } \\
\text { cause LGDP }\end{array}$ & $5.673 *$ & Reject & $\begin{array}{l}\mathrm{LM} \text { has a causal } \\
\text { relationship with LGDP }\end{array}$ \\
\hline
\end{tabular}

Notes: the $*, * *$ and $* * *$ indicate that the coefficients are significant at the $10 \%, 5 \%$ and $1 \%$ level of significance, respectively.

\section{Conclusion}

This paper has analysed the impact of trade openness to economic growth by using other important variables such as export, import, foreign direct investment, capital formation and exchange rate to perform the analysis. Based on the result of the long run estimation in Malaysia, LFDI and LREER have a larger impact on growth as compared to other variables. All variables contribute to long term development in Malaysia. This study suggests the importance of LFDI and LREER as indicators of the relationship between trade openness and economic growth. Thus, this study indicate that Malaysia should promote LFDI and LREER as engines to generate economic growth in this country.

The government of this country plays a significant role in increasing its economic growth by implementing policies. This will give more benefit by opening the country's economy to global trade. It was suggested that a country would gain more economic benefits by increasing its level of foreign direct investment and the exchange rate. This finding is correlated with other studies that suggested the importance of LFDI and LREER as indicators of the relationship between trade openness and economic growth. Thus, this study indicates that Malaysia should promote LFDI and LREER as engines to generate its economic growth. In this regard, increasing the opportunities for foreign direct investment will help increase investments from other countries and technological exchanges from developed countries.

Even though there is no evidence on the direct impact of trade openness on economic growth. As supported by the variables, foreign direct investment and exchange rate have helped accelerate economic growth in this country. Without openness, there will be no investment between two countries. Thus, it is safe to assume that trade openness has an important role in boosting the economic growth in Malaysia.

\section{Reference}

Abu Dalu, A. (2014). The Real Effective Exchange Rate Impact on ASEAN-5 Economic Growth. International Journal of Economics \& Management Sciences, 03(02).

Adhikary B.K, (2011) FDI, Trade Openness, Capital Formation and Economic Growth in Bangladesh: A Linkage Analysis. International Journal of Business and Management. Vol.6, No. 1

Bulent Ulaşan (2015) Trade Openness and Economic Growth: Panel Evidence, Applied Economics Letters, 22:2, 163-167 
Volume 2 Issue 5 (December 2020) PP. 55-63 DOI 10.35631/AIJBAF.25005

David A. Dickey and Wayne A. Fuller (1979) Distribution of the Estimators for Autoregressive Time Series With a Unit Root. Journal of the American Statistical Association, Vol. 74, No. 366 (Jun., 1979), pp.427-431

David M, Guillermo JO (2005) Economic Growth and Currency Crisis: a Real Exchange Rate Entropic Approach, Munich Personal REPEC Archive Paper No.211.

Grossman, G.M., \& Helpman, E. (1991). Innovation and Growth in the Global Economy, Cambridge, MA: MIT Pres

Hussin F \& Saidin N (2012) economic growth in ASEAN-4 countries: A Panel Data Analysis. International Journal of Economic and Finance. Vol.4, No.9.

Idris J, Yusop Z, \& Habibullah M. S. (2016) Trade Openness and Economic Growth: A Causality Test in Panel Perspective. International Journal of Business and Society. Vol. 17 No. 2, 281-290

Jawaid, S. T. (2014). Trade Openness and Economic Growth: A Lesson From Pakistan. Foreign Trade Review, 49(2), 193-212.

Keho, Y. 2017. The impact of trade openness on economic growth: The case of Cote d' Ivoire. Cogent Economics \& Finance, 8(1), 1-14.

Makun, K. 2017. Trade Openness and Economic Growth in Malaysia: Some Time-series Analysis, Foreign Trade Review 52(3) :157-170

Malcolm FM, Tzvetana R (1998) Exchange Rates and Economic Growth in Kenya: An Econometric Analysis, Development Discussion Paper No. 651

Merale fetahi-vehapi, Luljeta sadiku, \&mihail petkovski (2015). Empirical analysis of the effects of trade openness on economic growth: an evidence for south east European. Procedia economics and finance 19. 17-26

Musila, J. W., \& Yiheyis, Z. 2015. The impact of trade openness on growth: The case of Kenya. Journal of Policy Modeling, 37(2), 342-354.

Paresh Kumar Narayan(2004) Reformulating Critical Values for the Bounds F- statistics Approach to Cointegration: An Application to the Tourism Demand Model for Fiji. Department of Economics Discussion Papers ISSN 1441-5429 Monash University Victoria 3800 Australia

Pesaran, M.H., Shin, Y., \& Smith, R.J., 2001. Bounds Testing Approaches to The Analysis of Level Relationships, Journal of Applied Econometrics 16, 289-326.

Robert F. Engle; C. W. J. Granger (1987).Co-Integration and Error Correction: Representation, Estimation, and Testing. Econometrica, Vol. 55, No. 2. (Mar., 1987), pp. 251-276.

Sebastian Edwards (1993). Openness, trade liberalization and growth in developing countries. Jurnal of economic literature. Vol. 31, no 3. Pp 1358-1393

Vogiatzoglou,K. \& Nguyen,P,.N, T. 2016. Economic Openness and Economic Growth: A Cointegration Analysis for Asean-5 Countries, The European Journal of Applied Economics.13(2), 10-20. 